\title{
Evaluation of Different Grain Substrates for the Spawn Production of Pleurotus cornucopiae
}

\author{
R.S. Jarial ${ }^{1}$, Arunesh K. Sharma ${ }^{2}$, Kumud Jarial ${ }^{1}$ and Savita Jandaik ${ }^{2}$ \\ ${ }^{1}$ Department of Plant Pathology, College of Horticulture and Forestry, Neri, \\ Hamirpur (HP) - 177001, India \\ ${ }^{2}$ Department of Plant Pathology, Dr. Y. S. Parmar University of Horticulture and Forestry, \\ Nauni, Solan (HP) -173230, India \\ *Corresponding author
}

\section{A B S T R A C T}

\begin{tabular}{|l|} 
Key w o r d s \\
Pleurotus \\
cornucopiae, \\
Spawn substrates, \\
Fruit body, \\
Characters yield \\
\hline Article Info \\
\hline $\begin{array}{l}\text { Accepted: } \\
\text { 18 May } 2020 \\
\text { Available Online: } \\
\text { 20 June } 2020\end{array}$ \\
\hline
\end{tabular}

The cultivation of Pleurotus cornucopiae, the branched oyster mushroom is not very common in India but is relished for its pleasant flavour and mild taste. Grain substrates for its spawn production have not been evaluated yet but, wheat grains are commonly used for the same. So, five different grain substrates viz., wheat, barley, kodo, jowar and maize were tested, for spawn run period, mycelia growth, fruit body characters and yield of said mushroom on five different substrates. It was found that minimum time for spawn run was taken by jowar grains ( 7.33 days) and maximum was taken by kodo grains (16.00 days). In all the grains, type of growth ranged between fluffy to thick strand. However, during cropping, minimum time for spawn run was taken by jowar grain spawn (15.40 days) and maximum was taken by kodo grain spawn (22.26 days). Maximum number of basidioma was observed in wheat grain spawn (4.20) and minimum was observed in barley grain spawn (1.86). Fruit body characters like stipe length, fruit body length and cap diameter of $P$. cornucopiae was also recorded to be maximum in wheat grain spawn $((20.77 \mathrm{~mm}$, $26.40 \mathrm{~mm}$ and $35.94 \mathrm{~mm}$, respectively). Yield of $P$. cornucopiae was maximum (395.80 $\mathrm{g} / 2 \mathrm{~kg}$ substrates) on wheat grain spawn and minimum on kodo grain spawn $(207.00 \mathrm{~g} / 2 \mathrm{~kg}$ substrates). Among the different production substrates, maximum yield was recorded on paddy straw substrate $(338.20 \mathrm{~g} / 2 \mathrm{~kg}$ substrates $)$.

\section{Introduction}

Mushrooms are macro-fungi which may be epigeous or hypogeous and many of them are edible in nature. As these are fungal organisms, their cultivation requires a specific and scientific knowledge. Nowadays, mushroom cultivation has become a multimillion dollar industry in many countries of the world. The total mushroom production in world amounts to US\$ 25.00 billion (Wasser et al., 2000). India ranks at 4th position in terms of mushroom production (Anonymous, 2016 a). Mushroom production in World has been estimated at 10.790859 million MT and in India it is estimated to be 
29,992 tonnes (Anonymous, 2016 b). Commercially, button and oyster mushrooms are predominantly grown species followed by other tropical mushrooms like paddy straw and milky mushroom, etc.

Oyster mushroom ranks third in largest cultivated mushrooms in the world (Adebaya and Carrera, 2015). It is commonly called as 'Dhingri' in India because the shape of its fruit body resembles an oyster (Narain et al., 2016). These belong to genus Pleurotus of the class basidiomycetes and constitute a well known group of "white rot fungi" (Tsujiyama and Ueno, 2013). Their mycelium is white in colour and can be easily cultivated on any non-composted lignocellulosic substrates (Savoie et al., 2007). Many species of Pleurotus including $P$. ostreatus (oyster mushroom), P.eryngii (king oyster or Cardoncello), $P$. pulmonarius (phoenix mushroom), $P$. djamor (pink oyster mushroom), P. sajor-caju (Indian oyster), $P$. cystidiosus (abalone oyster), $P$. citrinopileatus (golden oyster mushroom) and $P$. cornucopiae (branched oyster mushroom) have considerable economic value and are cultivated commercially (Perez-Martinez et al., 2015). Oyster mushrooms are rich source of mineral salts such as $\mathrm{K}, \mathrm{Na}, \mathrm{P}, \mathrm{Fe}$ and $\mathrm{Ca}$ required by human body.

Pleurotus cornucopiae, the branched oyster mushroom, commonly known as "yellow dhingri" is one of the edible species of oyster mushroom. However, its cultivation is not very commonly in India but, it has a pleasant odour and mild taste. The species is characterized by a cap which is cream coloured when young and turns yellowochraceous to darker ochraceous to dark brown with maturity (Anonymous, 2012). Besides having nutritional and medicinal properties, its fruit bodies are also exploited in nutraceutical products, which play significant roles in providing good nutrition and improving human health (Alam et. al., 2011).

Spawn and spawn making are the primary requirements in mushroom cultivation which can be achieved by growing mushroom mycelia on any natural supporting medium under controlled aseptic conditions (Sofi et al., 2014). In almost all cases, the supporting medium is any sterilized grain preferred due to its biochemical properties and better performance over others (Siddhant et al., 2013). Generally, in India, wheat grains are the basal substrate for the spawn production of various species of edible mushrooms. But, efforts have always been made to find out some other suitable substrates for the same. There have been many reports in the literature regarding testing and usage of various types of grain substrates for the spawn production of different species of oyster mushroom (Asghar et al., 2007; Pal et al., 2008; Islam et al., 2009; Pathmashini et al., 2009; Stainley and Herbert, 2010 and Shukla and Jaitly, 2011). But, still there are no such reports in case of P. cornucopiae. Keeping this in mind, present investigations were conducted with an objective to evaluate different grain substrates for the spawn production of P. cornucopiae.

\section{Materials and Methods}

\section{Procurement of pure culture and preparation of mother culture}

The pure culture of $P$. cornucopiae was procured from Directorate of Mushroom Research, ICAR Complex, Solan and maintained on Potato Dextrose Agar medium in the refrigerator. For preparing the mother culture, wheat grains were used as substrate. The wheat grains were cleaned and then soaked in water for 2 hours. Rotten grains or those floating on the surface of water were removed. These grains were boiled in tap water for at least 10-15 minutes. Care was 
taken not to over cook the grains, so that they may not rupture. Excess water was drained off by keeping on a wire mesh for 8-10h. Lime (calcium carbonate) and gypsum (calcium sulphate) in the ratio of $1: 3(\mathrm{w} / \mathrm{w})$ were added to the boiled grains to prevent sticking of grains and for maintaining proper $\mathrm{pH}$.

Properly mixed grains were filled in bottles or polypropylene bags up to $2 / 3^{\text {rd }}$ of its capacity. These were then tightly plugged with non absorbent cotton (with the help of a plastic ring in case of polypropylene bags) and autoclaved at 22 psi pressure for $2 \mathrm{~h}$. The sterilized bags or bottles were taken out from autoclave, and to avoid clumping of grains while still hot, shaken vigorously. After cooling, these bottles or bags were immediately transferred to inoculation chamber and kept under UV light for minimum 35 minutes for surface sterilization.

Actively growing pure culture of test fungus $P$. cornucopiae was used for inoculation of these bottles/bags (Plate 1). Each bag was inoculated aseptically with two to three mycelial agar bits. The inoculated bottles/bags were then incubated at $25 \pm 1^{0} \mathrm{C}$ till the grains were fully impregnated with the mycelium of inoculated fungus culture (15-20 days) and were ready as master culture for further multiplication. These bottles/bags were stored at $4^{0} \mathrm{C}$ and used for further multiplication of spawn.

\section{Selection of suitable substrate for spawn production}

Different grain substrates viz., wheat grains, maize grains, jowar grains, barley grains and kodo grains were evaluated for their suitability to support fastest mycelial spread of the mushroom. The grains were used after boiling in the same way as wheat grains in case of mother culture preparation. Three replications of each treatment were kept and fresh mother culture prepared in each case was used as an inoculum. The inoculated bags were incubated in the BOD incubator at $25 \pm$ $1^{0} \mathrm{C}$. Data in terms of time taken for complete mycelial run (days) in grain spawn and type of mycelium (fluffy, dense, strandy) was recorded.

Spawn made on these grains was further evaluated in a production trial of P.cornucopiae on different agroforestry wastes viz., wheat straw, paddy straw, sugarcane bagasses, maize leaf straw and saw dust. These substrates were soaked in water to get fully wet and then treated with a solution of formalin $(0.5 \%)$ and carbendazim $(0.075 \%)$. The substrates were pressed and covered with polythene sheet overnight and used after draining excess of water. All these chemically treated substrates were then thoroughly spawned with different grain spawn at the rate of 2 per cent. These spawned substrates were then filled in the mushroom growing bags having $2 \mathrm{~kg}$ capacity and shifted to growing room. Standard mushroom growing package of practices was followed to raise the crop. Data were recorded in terms of time taken for complete spawn run (days), number of basidioma produced, characteristics of fruit body viz., stipe length $(\mathrm{mm})$, fruit body length $(\mathrm{mm})$, cap diameter $(\mathrm{mm})$ and yield $(\mathrm{g} / 2 \mathrm{~kg}$ substrate) of $P$. cornucopiae were recorded. Biological efficiency $(\%)$ of tested agroforestry wastes in relation to different grain spawn was calculated further by adopting following formula.

\section{Biological Efficiency $(\%)=$ $\frac{\text { Fresh weight of the mushroom }}{\text { Dry weight of substrate }} \times 100$}

\section{Results and Discussion}

It is clear from Table 1 that the shortest spawn run period ( 7.33 days) was recorded in case of jowar grain spawn which was statistically at 
par with that of wheat grain spawn (8.33 days), significantly followed by maize grain spawn (11 days) and barley grain spawn (13 days). However, significantly longest period (16 days) for spawn run was recorded in case of kodo grain spawn. As far as type of mycelium was concerned, it ranged from thick strandy in wheat grain spawn to thin strandy in jowar and kodo grain spawn and fluffy to dense fluffy in case of barley and maize grain spawn, respectively (Plate 2).

Spawn produced on different grain substrates was further evaluated for cultivation of $P$. cornucopiae on five different substrates during the course of studies and data recorded have been presented in Table 2, 3, 4, 5 and 6 .

The data presented in the Table 2 reveal the time taken for spawn run on different substrates spawned with various grain spawn under study. It is clear from the table that irrespective of the different substrates used, minimum average time (15.40 days) for spawn run was taken by jowar grain spawn significantly followed by maize grain spawn (16.96 days) and wheat grain spawn (18.03 days). However, significantly maximum time for spawn run was taken by kodo grain spawn (22.26 days) significantly followed by barley grain spawn (19 days) on different substrates used for the cultivation of $P$. cornucopiae (Plate 9). Irrespective of the different grain spawn used, the minimum time (16.30 days) for spawn run was observed on wheat straw substrate which was statistically at par with paddy straw substrate (16.66 days). Saw dust took significantly maximum time (21.50 days) for spawn run followed by maize straw (19.10 days) and sugarcane bagasse (18.10 days). Body of the table reveal that minimum time taken for spawn run was observed in wheat straw substrate (13.50 days) spawned with jowar grain spawn which was statistically at par with paddy straw substrate (14.66 days) spawned with jowar grain spawn. However, maximum time taken for spawn run was recorded in saw dust $(27.00$ days) spawned with kodo grain spawn which was followed significantly by maize straw (24.00 days) spawned with kodo grain spawn.

Data recorded on number of fruit bodies produced on different substrates spawned with grain spawn under study have been presented in Table 3. It is clear from the table that irrespective of the different substrates used, wheat grain spawn produced maximum (4.20) average number of basidioma which was followed significantly by maize grain spawn (3.40). However, least (1.86) average no of basidioma were observed in barley grain spawn which was statistically at par with kodo grain spawn (2.00). Irrespective of the different grain spawn used, maximum (4.40) number of basidioma was recorded in wheat straw substrate which was statistically at par with paddy straw substrate (4.00) whereas, minimum number of basidioma (1.26) was produced by saw dust substrate significantly followed by maize straw (2.06) substrate (Plate $3 \& 4)$. Body of the table reveal that maximum (7.00) number of basidioma were produced in wheat straw spawned with wheat grain which was at par with those produced in same substrate spawned with maize grain spawn (6.33) and paddy straw substrate (6.33) spawned with wheat grain spawn. However, minimum (1.00) number of basidioma was recorded in saw dust spawned with barley and kodo grain spawn which was statistically at par with same substrate spawned with jowar, maize and wheat grain spawn.

The data recorded on stipe length of basidioma on different substrates spawned with different grain spawn have been presented in Table 4 . It can be inferred from the table that irrespective of the different substrates used, wheat grain spawn produced longest $(20.77 \mathrm{~mm})$ stipe which was at par with jowar grain spawn $(20.61 \mathrm{~mm})$ and 
maize grain spawn (20.47 $\mathrm{mm})$. However, shortest $(18.72 \mathrm{~mm})$ stipe length was observed in barley grain spawn non significantly followed by kodo grain spawn $(18.88 \mathrm{~mm})$. Irrespective of the different grain spawn used, the maximum $(22.71 \mathrm{~mm})$ stipe length was recorded in wheat straw substrate which was at par with that in paddy straw substrate $(22.68 \mathrm{~mm})$. Minimum $(13.86 \mathrm{~mm})$ stipe length was observed in saw dust significantly followed by maize straw (19.46 $\mathrm{mm})$. Body of the table reveal that maximum (24.31 mm) stipe length was recorded in paddy straw substrate spawned with jowar grain spawn which was statistically at par with wheat straw substrate $(23.92 \mathrm{~mm})$ spawned with wheat grain spawn. However, minimum $(11.00 \mathrm{~mm})$ stipe length was recorded in saw dust substrate spawned with kodo grain spawn non significantly followed by same substrate $(12.16 \mathrm{~mm})$ spawned with barley grain spawn.

The data presented in Table 5 depict the average length of fruit bodies harvested from different substrates spawned with various grain spawn. Data indicated that irrespective of the different substrates used, wheat grain spawn produced longest $(26.40 \mathrm{~mm})$ fruit bodies which was significantly followed by maize grain spawn $(19.70 \mathrm{~mm})$ and jowar grain spawn (19.39 $\mathrm{mm})$.

The fruit body length in latter two treatments was statistically at par with each other. However, shortest $(13.08 \mathrm{~mm})$ fruit bodies were observed in kodo grain spawn non significantly followed by barley grain spawn $(13.96 \mathrm{~mm})$. Irrespective of different grain spawn used, maximum $(23.43 \mathrm{~mm})$ average fruit body length was observed on wheat straw substrate which was statistically at par with paddy straw substrate $(22.59 \mathrm{~mm})$. However, minimum $(12.90 \mathrm{~mm})$ mean fruit body length was observed in saw dust significantly followed by maize straw substrate $(15.99 \mathrm{~mm})$ and sugarcane bagasse $(17.62 \mathrm{~mm})$. Body of the table reveal that maximum $(38.88 \mathrm{~mm})$ length of fruit body was recorded in wheat straw substrate spawned with wheat grain spawn which was at par with paddy straw substrate $(36.14 \mathrm{~mm})$ spawned with wheat grain spawn. However, minimum $(10.88 \mathrm{~mm})$ length of fruit body was observed in sugarcane bagasse substrate spawned with kodo grain spawn non significantly followed by maize straw substrate $(11.33 \mathrm{~mm})$ spawned with kodo grain spawn.

The data presented in Table 6 reveal average diameter of sporocarps. From the table, it is clear that irrespective of the different substrates used, wheat grain spawn produced maximum $(35.94 \mathrm{~mm})$ sporocarp diameter which was significantly followed by maize grain spawn $(30.81 \mathrm{~mm})$. However, minimum $(21.82 \mathrm{~mm})$ fruit body cap diameter was observed in jowar grain spawn non significantly followed by kodo grain spawn $(23.21 \mathrm{~mm})$. Irrespective of the different grain spawn used, wheat straw substrate produced maximum $(41.01 \mathrm{~mm})$ sporocarp diameter which was significantly followed by paddy straw substrate $(34.95 \mathrm{~mm})$. However, minimum $(16.62 \mathrm{~mm})$ sporocarp diameter was observed in saw dust substrate significantly followed by maize straw substrate $(22.32 \mathrm{~mm})$ and sugarcane bagasse ( $25.15 \mathrm{~mm}$, Plate 12). Body of the table reveal that maximum $(55.96 \mathrm{~mm})$ sporocarp diameter was observed in wheat straw substrate spawned with wheat grain spawn which was at par with same substrate $(51.88$ mm) spawned with maize grain spawn. However, minimum (12.75 $\mathrm{mm})$ sporocarp diameter was recorded in saw dust substrate spawned with kodo grain spawn non significantly followed by same substrate (13.41 mm) spawned with barley grain spawn. 
Table.1 Effect of different grains substrates on spawn production of Pleurotus cornucopiae

\begin{tabular}{|c|c|l|}
\hline Grain substrates & Spawn run period (days) & \multicolumn{1}{|c|}{ Type of mycelium } \\
\hline Wheat & 8.33 & Thick strandy \\
\hline Maize & 11.00 & Dense fluffy \\
\hline Jowar & 7.33 & Thin strandy \\
\hline Barley & 13.00 & Fluffy \\
\hline Kodo & 16.00 & Thin strandy \\
\hline Mean & 11.13 & \\
\hline SE & 0.69 & \\
\hline CD & 1.55 & \\
\hline
\end{tabular}

Table.2 Effect of different grain spawn on spawn run period of Pleurotus cornucopiae in different substrates

\begin{tabular}{|l|c|c|c|c|c|c|}
\hline \multirow{2}{*}{ Grain spawn } & \multicolumn{5}{|c|}{ Average time taken for spawn run in substrates (days) } \\
\cline { 2 - 6 } & Wheat straw & Paddy straw & Sugarcane & Maize & Saw & Mean \\
bagasse & & & straw & dust & \\
\hline Wheat & 16.16 & 17.33 & 17.50 & 18.66 & 20.50 & 18.03 \\
\hline Maize & 15.00 & 15.50 & 17.33 & 17.00 & 20.00 & 16.96 \\
\hline Jowar & 13.50 & 14.66 & 15.00 & 15.83 & 18.00 & 15.40 \\
\hline Barley & 17.50 & 17.00 & 18.50 & 20.00 & 22.00 & 19.00 \\
\hline Kodo & 19.33 & 18.83 & 22.16 & 24.00 & 27.00 & 22.26 \\
\hline Mean & 16.30 & 16.66 & 18.10 & 19.10 & 21.50 & \\
\hline & SE & CD & & & & \\
\hline Grain & 0.22 & 0.64 & & & & \\
\hline Substrate & 0.22 & 0.64 & & & \\
\hline Interaction & 0.50 & 1.43 & & & \\
\hline
\end{tabular}


Table.3 Effect of different grain spawn on fruit body production of Pleurotus cornucopiae in different substrates

\begin{tabular}{|c|c|c|c|c|c|c|}
\hline \multirow{2}{*}{ Grain spawn } & \multicolumn{5}{|c|}{ Average number of basidioma in different substrates } \\
\cline { 2 - 6 } & $\begin{array}{c}\text { Wheat } \\
\text { straw }\end{array}$ & $\begin{array}{c}\text { Paddy } \\
\text { straw }\end{array}$ & $\begin{array}{c}\text { Sugarcane } \\
\text { bagasse }\end{array}$ & $\begin{array}{c}\text { Maize } \\
\text { straw }\end{array}$ & Saw dust & Mean \\
\hline Wheat & 7.00 & 6.33 & 3.66 & 2.66 & 1.33 & 4.20 \\
\hline Maize & 6.33 & 5.00 & 2.33 & 2.00 & 1.33 & 3.40 \\
\hline Jowar & 3.00 & 4.00 & 2.00 & 2.33 & 1.66 & 2.60 \\
\hline Barley & 2.66 & 2.00 & 1.66 & 2.00 & 1.00 & 1.86 \\
\hline Kodo & 3.00 & 2.66 & 2.00 & 1.33 & 1.00 & 2.00 \\
\hline Mean & 4.40 & 4.00 & 2.33 & 2.06 & 1.26 & \\
\hline & SE & CD & & & & \\
\hline Grain & 0.25 & 0.72 & & & & \\
\hline Substrate & 0.25 & 0.72 & & & & \\
\hline Interaction & 0.57 & 1.62 & & & & \\
\hline
\end{tabular}

Table.4 Effect of different grain spawn on stipe length of Pleurotus cornucopiae in different substrates

\begin{tabular}{|l|c|c|c|c|c|c|}
\hline \multirow{2}{*}{ Grain spawn } & \multicolumn{7}{|c|}{ Average stipe length in different substrates (mm) } \\
\cline { 2 - 7 } & $\begin{array}{c}\text { Wheat } \\
\text { straw }\end{array}$ & $\begin{array}{c}\text { Paddy } \\
\text { straw }\end{array}$ & $\begin{array}{c}\text { Sugarcane } \\
\text { bagasses }\end{array}$ & $\begin{array}{c}\text { Maize } \\
\text { straw }\end{array}$ & Saw dust & Mean \\
\hline Wheat & 23.92 & 22.57 & 21.33 & 19.38 & 16.66 & 20.77 \\
\hline Maize & 22.85 & 23.37 & 20.83 & 19.16 & 16.16 & 20.47 \\
\hline Jowar & 22.47 & 24.31 & 22.00 & 20.94 & 13.33 & 20.61 \\
\hline Barley & 21.94 & 21.33 & 18.50 & 19.66 & 12.16 & 18.72 \\
\hline Kodo & 22.38 & 21.83 & 21.05 & 18.16 & 11.00 & 18.88 \\
\hline Mean & 22.71 & 22.68 & 20.74 & 19.46 & 13.86 & \\
\hline & $\mathrm{SE}$ & $\mathrm{CD}$ & & & & \\
\hline Grain & 0.21 & 0.60 & & & & \\
\hline Substrate & 0.21 & 0.60 & & & & \\
\hline Interaction & 0.47 & 1.35 & & & & \\
\hline
\end{tabular}


Table.5 Effect of different grain spawn on fruit body length in different substrate of Pleurotus cornucopiae

\begin{tabular}{|l|c|c|c|c|c|c|}
\hline \multirow{2}{*}{ Grain spawn } & \multicolumn{5}{|c|}{ Average Fruit body length in different substrates (mm) } \\
\cline { 2 - 7 } & $\begin{array}{c}\text { Wheat } \\
\text { straw }\end{array}$ & $\begin{array}{c}\text { Paddy } \\
\text { straw }\end{array}$ & $\begin{array}{c}\text { Sugarcane } \\
\text { bagasse }\end{array}$ & $\begin{array}{c}\text { Maize } \\
\text { straw }\end{array}$ & Saw dust & Mean \\
\hline Wheat & 38.88 & 36.14 & 25.41 & 18.77 & 12.83 & 26.40 \\
\hline Maize & 24.12 & 23.97 & 18.00 & 17.94 & 14.50 & 19.70 \\
\hline Jowar & 23.38 & 23.62 & 19.83 & 18.61 & 11.50 & 19.39 \\
\hline Barley & 13.99 & 16.50 & 14.00 & 13.33 & 12.00 & 13.96 \\
\hline Kodo & 16.80 & 12.72 & 10.88 & 11.33 & 13.66 & 13.08 \\
\hline Mean & 23.43 & 22.59 & 17.62 & 15.99 & 12.90 & \\
\hline & SE & CD & & & & \\
\hline Grain & 0.60 & 1.70 & & & & \\
\hline Substrate & 0.60 & 1.70 & & & & \\
\hline Interaction & 1.34 & 3.82 & & & & \\
\hline
\end{tabular}

Table.6 Effect of different grain spawn on cap diameter of Pleurotus cornucopiae in different substrates

\begin{tabular}{|l|c|c|c|c|c|c|}
\hline \multirow{2}{*}{ Grain spawn } & \multicolumn{5}{|c|}{ Average cap diameter in different substrates (mm) } \\
\cline { 2 - 6 } & $\begin{array}{c}\text { Wheat } \\
\text { straw }\end{array}$ & $\begin{array}{c}\text { Paddy } \\
\text { straw }\end{array}$ & $\begin{array}{c}\text { Sugarcane } \\
\text { bagasse }\end{array}$ & $\begin{array}{c}\text { Maize } \\
\text { straw }\end{array}$ & Saw dust & Mean \\
\hline Wheat & 55.96 & 45.20 & 32.05 & 26.06 & 20.45 & 35.94 \\
\hline Maize & 51.88 & 35.48 & 25.05 & 20.77 & 20.87 & 30.81 \\
\hline Jowar & 29.88 & 26.84 & 17.81 & 18.94 & 15.62 & 21.82 \\
\hline Barley & 40.34 & 34.37 & 29.08 & 24.12 & 13.41 & 28.26 \\
\hline Kodo & 27.00 & 32.86 & 21.76 & 21.70 & 12.75 & 23.21 \\
\hline Mean & 41.01 & 34.95 & 25.15 & 22.32 & 16.62 & \\
\hline & SE & CD & & & & \\
\hline Grain & 0.71 & 2.04 & & & & \\
\hline Substrate & 0.71 & 2.04 & & & & \\
\hline Interaction & 1.60 & 4.56 & & & & \\
\hline
\end{tabular}


Table.7 Yield of Pleurotus cornucopiae as influenced by different grain spawn on different substrates

\begin{tabular}{|c|c|c|c|c|c|c|}
\hline \multirow[t]{2}{*}{ Grain spawn } & \multicolumn{6}{|c|}{ Average Yield (g/2kg substrates) in different substrates } \\
\hline & $\begin{array}{l}\text { Wheat } \\
\text { Straw }\end{array}$ & $\begin{array}{l}\text { Paddy } \\
\text { Straw }\end{array}$ & $\begin{array}{c}\text { Sugarcane } \\
\text { Bagasse }\end{array}$ & $\begin{array}{l}\text { Maize } \\
\text { Straw }\end{array}$ & Saw Dust & Mean \\
\hline Wheat & $\begin{array}{l}496.00 \\
(82.66)\end{array}$ & $\begin{array}{l}480.00 \\
(80.00)\end{array}$ & $\begin{array}{l}463.00 \\
(71.66)\end{array}$ & $\begin{array}{l}388.00 \\
(64.66)\end{array}$ & $\begin{array}{l}185.00 \\
(30.83)\end{array}$ & 395.80 \\
\hline Maize & $\begin{array}{l}363.00 \\
(60.50)\end{array}$ & $\begin{array}{l}397.00 \\
(66.16)\end{array}$ & $\begin{array}{l}328.66 \\
(54.77)\end{array}$ & $\begin{array}{l}252.00 \\
(42.00)\end{array}$ & $\begin{array}{l}130.00 \\
(21.66)\end{array}$ & 294.13 \\
\hline Jowar & $\begin{array}{l}276.66 \\
(46.11)\end{array}$ & $\begin{array}{l}307.00 \\
(51.16)\end{array}$ & $\begin{array}{l}243.00 \\
(40.50)\end{array}$ & $\begin{array}{l}215.00 \\
(35.83)\end{array}$ & $\begin{array}{l}113.00 \\
(18.83)\end{array}$ & 230.93 \\
\hline Barley & $\begin{array}{l}278.00 \\
(46.33)\end{array}$ & $\begin{array}{l}249.00 \\
(41.50)\end{array}$ & $\begin{array}{l}223.00 \\
(37.16)\end{array}$ & $\begin{array}{l}197.00 \\
(32.83)\end{array}$ & $\begin{array}{c}108.00 \\
(18.00)\end{array}$ & 211.00 \\
\hline Kodo & $\begin{array}{l}234.00 \\
(39.00)\end{array}$ & $\begin{array}{l}258.00 \\
(43.00)\end{array}$ & $\begin{array}{l}240.00 \\
(40.00)\end{array}$ & $\begin{array}{l}205.00 \\
(34.16)\end{array}$ & $\begin{array}{c}98.00 \\
(16.33)\end{array}$ & 207.00 \\
\hline Mean & 329.53 & 338.20 & 292.93 & 251.40 & 126.80 & \\
\hline & SE & $\mathrm{CD}$ & & & & \\
\hline Grain & 3.64 & 10.37 & & & & \\
\hline Substrate & 3.64 & 10.37 & & & & \\
\hline Interaction & 8.14 & 23.19 & & & & \\
\hline
\end{tabular}

Figures in parentheses represent respective biological efficiency (\%)

The data presented in Table 7 reveal the average mushroom yield and biological efficiency of different substrates spawned with various grain spawn. From the table it is clear that irrespective of the different substrates used, wheat grain spawn produced maximum average yield $(395.80 \mathrm{~g} / 2 \mathrm{~kg}$ substrate) which was followed significantly by maize grain spawn $(294.13 \mathrm{~g} / 2 \mathrm{~kg}$ substrate) and jowar grain spawn (230.93 $\mathrm{g} / 2 \mathrm{~kg}$ substrate). Minimum yield was observed in kodo grain spawn $(207.00 \mathrm{~g} / 2 \mathrm{~kg}$ substrate) which was statistically at par with barley grain spawn $(211.00 \mathrm{~g} / 2 \mathrm{~kg}$ substrate). Irrespective of the different grain spawn used, paddy straw substrate produced maximum average yield (338.20 g/2kg substrate) which was statistically at par with wheat straw substrate (329.53 g/2kg substrate). However, minimum yield (126.80 g/2kg substrate) was recorded in saw dust significantly followed by maize straw (251.40 g/2kg substrate) and sugarcane bagasse $(292.93 \mathrm{~g} / 2 \mathrm{~kg}$ substrate). Interaction of the table clearly depicts that maximum yield (496.00 g/2kg substrate) was recorded in wheat straw substrate spawned with wheat grain spawn which was statistically at par with paddy straw substrate spawned with wheat grain spawn (480.00 $\mathrm{g} / 2 \mathrm{~kg}$ substrate). The latter was further at par with the yield in sugarcane bagasses spawned with wheat grain spawn $(463.00 \mathrm{~g} / 2 \mathrm{~kg}$ substrate). However, minimum yield (98.00 $\mathrm{g} / 2 \mathrm{kgsubstrate)}$ was recorded in saw dust substrate spawned with kodo grain spawn non significantly followed by same substrate spawned with barley grain spawn(108.00 $\mathrm{g} / 2 \mathrm{~kg}$ substrate) and jowar grain spawn (113.00 g/2kg substrate). Biological efficiency was recorded to be maximum $(82.66 \%)$ in wheat straw substrate spawned with wheat grain spawn followed by paddy 
straw substrate $(80.00 \%)$ spawned with same grain spawn whereas, minimum biological efficiency (16.33\%) was recorded in saw dust spawned with kodo grain spawn.

In the present studies, minimum spawn run period was recorded in case of jowar grain spawn which was statistically at par with wheat grain spawn and significantly maximum spawn run period was recorded in case of kodo grain spawn. Good growth of different Pleurotus spp. on jowar, bajra and wheat grains may be due to the presence of starch which is known to favour mycelial growth of $P$. ostreatus (Hashimoto and Takahashi, 1974). Similar findings regarding jowar as a good grain substrate for Pleurotus species have been reported by Moorthy (1981), who found jowar grains to be a cheap and popular substrate for spawn production. More or less similar results were also obtained by Sharma (2003) with $P$. djamor.

The spawn run period in different substrates was recorded to range between 15 to 22 days being minimum in jowar grain and maximum in kodo grain spawn irrespective of substrates used. These results are in conformity with the findings of Jongman et al., (2013) who reported a spawn run period ranging between 12 to 16 days on maize substrate spawned with wheat, bajra and sorghum grain spawn. However, irrespective of the grain spawn used, minimum time for spawn run was observed in wheat straw substrate being statistically at par with paddy straw substrate while, maximum time for spawn run was recorded in saw dust substrate. These results are in conformity with the findings of Gimay et al., (2016) who reported a spawn run period of 15.67 days on wheat straw and 19.67 days on saw dust spawned with sorghum grain spawn.

Different fruit body characters like stipe length, fruit body length and cap diameter of
P. cornucopiae as influenced by different grain spawn grown on various substrates were studied during present investigations. Maximum stipe length, fruit body length and cap diameter was recorded in wheat grain spawn raised on wheat straw. These resulted are supported with the findings of Owaid et al., (2016) who reported average cap diameter of $58.1 \pm 3.4 \mathrm{~mm}$ and average stipe length of $35.7 \pm 4.21 \mathrm{~mm}$ in $P$. ostreatus raised on different substrates. Further, Mohamed et al., (2016) also recorded average cap diameter ranging from 85.00 to $146.7 \mathrm{~mm}$ and stipe length varying between 25 to $60 \mathrm{~mm}$ in case of $P$. columbines grown on rice straw or raw corn straw formulations. The findings of Jaichandran et al., (2017) further support our results who reported average cap diameter 38 $\pm 21 \mathrm{~mm}$ and stipe length $28 \pm 19 \mathrm{~mm}$ in case of $P$. florida grow on wheat grains.

These results obtained on yield and biological efficiency are in agreement with the findings of Islaam et al., (2009); Pal et al., (2008) and Rathore and Thakore (2014), who also reported wheat grain spawn to be best in terms of yield performance of different Pleurotus spp under studies. On the contrary, Jaichandran et al., (2017) have reported a biological efficiency of 56.64 per cent in case of $P$. florida raised from wheat grain spawn on paddy straw substrate.

\section{References}

Adebaya, E.A. and Martinez-Carrera, D. (2015). Oyster mushrooms (Pleurotus) are useful for utilizing lignocellulosic biomass. African Journal of Biotechnology 14, 52-67.

Alam. N., Yoon, K.N., Lee, J.S., Cho, H.J., Shim, M.J. and Lee, T.S. (2011). Dietary effect of Pleurotus eryngii on biochemical function and histology in hypercholesterolemic rats. Saudi journal of biological sciences 18, 403-409. 
Anonymous. (2012). Some of the most important cultivated oyster mushroom species. Mushroomers Club. www.htttp//:mushroomersclub.blogspot. com/2012/07/12

Anonymous. (2016a). Mushroom production http://www.indiastat.com

Anonymous. (2016b). Quarterly bulletin of statistics. Food and Agriculture Organisation, Rome, http://www.fao.org

Asghar, R., Tariq, M.U. and Rehman, T.A. (2007). Propagation of Pleurotus sajorcaju (oyster mushroom) through tissue culture. Pakistan Journal of Botany 39, 1383-1386.

Gimay, Z., Gorems, W., Birhanu, G. and Zewdie, S. (2016). Growth and yield performance of Pleurotus ostreatus (Jacq. Fr.) Kumm (Oyster mushroom) on different substrates. AMB Express. 6,87

Hashimoto and Takahashi, Z. (1974). Studies on the growth of Pleurotus ostreatus. Mushroom Science 9, 585593.

Islam, M.Z., Rahman, M.H. and Hafiz, F. (2009). Cultivation of oyster mushroom (Pleurotus flabellatus) on different substrate. International Journal of Sustainable Crop Production 4, 45-48.

Jaichandran, A., Nadesan, S. and Murugaiyan, K. (2017). Comparative study of different grains on spawn development of Pleurotus florida. International. Journal of Science Inventions Today 6, 728-735.

Jongman, M., Khare, K.B. and Khonga, E.B. (2013). Effect of different grain spawns and substrate sterilization methods on yield of oyster mushroom in Botswana. International Journal of Bioassays 2, 1308-1311.

Mohamed, M.F., Refaei, E.F., Abdalla, M.M. and Abdelgalil, S.H. (2016). Fruiting bodies yield of oyster mushroom (Pleurotus columbinus) as affected by different portions of compost in the substrate. International Journal of Recycling of Organic Waste in Agriculture 5(4), 281-288.

Moorthy, V.K. (1981). Microbial and chemical studies on the cultivation of oyster mushroom (Pleurotus sajar Caju) in paddy straw. M. Sc. thesis. Punjab Agricultural University, Ludhiana. 105p.

Narain, S., Singh, A.K. and Chauhan, J. (2016). Capacity of farmers to pay for extension services. Indian Research Journal of Extension Education 11, 6062.

Owaid, M.N., Aved, I.A. and Al-Seedi, S.S.S. (2016). Properties of fruit body of Oyster mushroom (Pleurotus ostreatus) cultivated on some local cellulosic residues in Iraq. GIDA 41, 189-195.

Pal, D.P., Shukla, C.S., Deo, A.K. and Tripathi, M.K. (2008). Effect of grain substrate on spawn run, pinhead and yield of wild Pleurotus spp. and Pleurotus eous. Plant Archives 8, 401402.

Pathmashini, L., Arulnandhy, V. and Wijeratnam, R.S. (2009). Cultivation of oyster mushroom (Pleurotus ostreatus) on sawdust. Ceylon Journal of Science (Biological Sciences) 37, 177-182.

Pérez-Martínez, A.S., Acevedo-Padilla, S.A., Bibbins-Martínez, M., Galván-Alonso, J. and Rosales-Mendoza, S. (2015). A perspective on the use of Pleurotus for the development of convenient fungimade oral subunit vaccines. Vaccine. 33, 25-33.

Rathore, V.R. and Thakore, B.B. (2004). Effect of different substrates on the production and nutritional value of sporophores of Pleurotus florida (Eger) Nom. Nud. Journal of Mycology and Plant Pathology 34, 66-68

Savoie, J.M., Salmones, D. and, Mata, G. (2007). Hydrogen peroxide 
concentration measured in cultivation substrates during growth and fruiting of the mushrooms Agaricus bisporus and Pleurotus spp. Journal of the Science of Food and Agriculture 87, 1337-1344.

Sharma, B.B. (2003). Effect of different substrates (Grains/straws) on spawn growth and yield of pink oyster mushroom Pleurotus djamor (Fr.) Boedign. Journal of Mycology and Plant Patholology 33, 265-268

Shukla, S. and Jaitly, A.K. (2011). Morphological and biochemical characterization of different Oyster mushroom (Pleurotus spp.). Journal of Phytology 3(8), 18-20.

Siddhant, Swapnil, Y. and Singh, C.S. (2013). Spawn and Spawning Strategies for the Cultivation of Pleurotus eous (Berkeley) Saccardo. International Journal of Pharmaceutical and Chemical Science 2(3), 1494-1500.

Sofi, B., Ahmad, M. and Khan, M. (2014).
Effect of different grains and alternate substrates on oyster mushroom (Pleurotus ostreatus) production. African Journal of Microbiology Research 8, 1474-1479.

Stainley, H.O. and Herbert, O. (2010). Effect of substrates of spawn production on mycelial growth of oyster mushroom spp. Agriculture and Biology Journal of North America 1(5), 817-820.

Tsujiyama, S. and Ueno, H. (2013). Performance of wood-rotting fungibased enzymes on enzymic saccharification of rice straw. Journal of the Science of Food and Agriculture 93, 2841-2848.

Wasser, S.P., Sokolov, D., Reshetnikov, S.V. and Timor-Tismenetsky, M. (2000). Dietary supplements from medicinal mushrooms: diversity of types and variety of regulations. International Journal of Medicinal Mushrooms 2, 119.

\section{How to cite this article:}

Jarial, R.S., Arunesh K. Sharma, Kumud Jarial and Savita Jandaik. 2020. Evaluation of Different Grain Substrates for the Spawn Production of Pleurotus cornucopiae. Int.J.Curr.Microbiol.App.Sci. 9(06): 1689-1700. doi: https://doi.org/10.20546/ijcmas.2020.906.209 